\title{
FAKTOR-FAKTOR YANG MEMPENGARUHI KADAR ASAM URAT PADA USIA PRODUKTIF DI DESA NONGAN, KABUPATEN KARANGASEM
}

\section{FACTORS AFFECTING URIC ACID LEVEL AT PRODUCTIVE AGE IN NONGAN VILLAGE, KARANGASEM REGENCY}

\author{
Rai Wiwik Dwi Astari ${ }^{1}$, Ni Ketut Ayu Mirayanti², I Made Arisusana ${ }^{3}$. \\ STIKes Wira Medika Bali ${ }^{1,2,3}$
}

\begin{abstract}
ABSTRAK
Pendahuluan: Usia produktif dengan rentang usia dari 18-45 tahun, merupakan usia dimana manusia sudah matang secara fisik dan biologis. Tidak sedikit masyrakat dengan usia produktif yang sudah merasakan beberapa gejala adanya penyakit degeneratif yaitu contohnya penyakit asam urat. Penyakit asam urat adalah jenis arthiritis yang sangat menyakitkan yang disebabkan oleh penumpukan kristal persendian. Tujuan Penelitian mengetahui faktor-faktor yang mempengaruhi kadar asam urat darah pada usia produktif di Desa Nongan, Kabupaten Karangasem. Metode: Jenis penelitian ini adalah korelasional dan pendekatan yang digunakan adalah cross-sectional. Jumlah sampel pada penelitian ini adalah 58 responden dengan Non- probability sample yaitu dengan Random sampling. Hasil: Hasil analisis statistik dengan menggunakan rank spearman menunjukan bahwa dari 4 variabel yaitu makanan dengan $\mathrm{p}$ value $=0,000$, aktifitas fisik dengan $\mathrm{p}$ value $=$ 0,001 , tingkat pengetahuan dengan $p$ value $=0,000$, jenis kelamin dengan $p$ value $=0,000$ lebih kecil dari pada 0,05 maka ada hubungan yang bermakna antara makanan, tingkat pengetahuan, aktifitas fisik, jenis kelamin dengan Kadar Asam Urat pada Usia Produktif di Desa Nongan.
\end{abstract}

\section{Kata Kunci: asam urat, usia produktif}

\section{ABSTRACT}

Introduction: Productive age with age range from 18-45 years old, is the age which is human are mature physically and biologidally. Not afew peoples with productive age who al ready feel some sign of degenative disease for example uric acid disease. Uric acid disease is the arthritis type that very painfull uaused by cumulation of crystal joint. The purpose of this study to know factors that influence blood uric acid levels in productive age at Nongan village, Kabupaten Karangasem. Method: The type of this study is cross - sectional. The amount sample of this study is 58 respondents with Non -probability sample thatis Random sampling technique. Result: Statistical analysis results using rank spearman show that from 4 variables that is food with $p$ value $=0,000$, physical activity with $p$ value $=0,001$, knowledge levels with $p$ value $=0,000$, gender with $p$ value $=0,000$ smaller than 0,05 so there is a meaning ful correlation between food, knowledge levels, physical activity, gender with Uric acid levels in productive age at Nongan village.

Keywords: uric acid, productive age 


\begin{tabular}{ll}
\hline Alamat Korespondensi & : STIKes Wira Medika Bali \\
Email & wiwikastari29@gmail.com \\
\hline
\end{tabular}

\section{PENDAHULUAN}

Usia produktif adalah usia produktif dengan rentang usia dari 18-45 tahun, merupakan usia dimana manusia sudah matang secara fisik dan biologis. Pada usia inilah manusia sedang berada pada puncak aktivitasnya. Aktivitas fisik yang dilakukan cenderung lebih berat dari pada usia lainnya. Pada aktivitas sering memicu timbulnya stress yang juga merupakan penyakit yang sering menghinggapi masyarakat. Timbulnya stress dapat mengubah fungsi-fungsi normal tubuh dan dalam rentang waktu lama berjuang pada kemunculan dini gejala penyakit degeneratif (Adam Maulana Zuhelsya, 2016).

Maka biasanya masalah yang sering muncul pada usia produktif yaitu mengeluh nyeri pada bagian persendian seperti nyeri pada bagian jari- jari kaki, dengkul, tumit, pergelangan tangan, jari tangan dan siku. Dimana dari masalah kesehatan tersebut dapat memicu terjadinya asam urat (Adam Maulana Zuhelsya, 2016).

Pravelensi asam urat pada populasi di USA diperkirakan 13,6/100.000 penduduk, sedangkan di Indonesia sendiri diperki rakan 1,6-13,6/100.000 orang, pravelensi ini meningkat seiring dengan meningkatnya umur (Pipit, 2010).

Hasil survei WHO justru menunjukkan rincian bahwa di Indonesia penyakit asam urat $35 \%$ terjadi pada pria di bawah usia 34 tahun. Sementara itu juga disebutkan bahwa Indonesia merupakan negara terbesar ke 4 di dunia yang penduduknya menderita asam urat.

Berdasarkan hasil studi pendahuluan pada tanggal 4 dan 5 Maret 2018, di Puskesmas Rendang Kabupaten Karangasem pada tanggal 4 peneliti melakuakan pengambilan data yang diberiakan oleh pihak Puskesmas Rendang Kabupaten Karangasem, namun dari data yang diambil pada tanggal 4 tersebut tidak cukup maka peneliti kembali melakukan pengambilan data pada tanggal 5 untuk mendapatkan data yang cukup. Maka di dapatkan data di Banjar Bukian karangasem sebesar 30 orang dengan usia produktif yang mengalami asam urat, Banjar Manggaan sebanyak 22 orang usia produktif yang mengalami asam urat. Banjar Saren sebanyak 15 orang usia produktif yang mengalami asam urat. Dari hasil pengukuran kadar asam urat dan wawancara yang dilakukan di Banjar Bukian, Banjar Manggan, Banjar Saren sebanyak 67 usia poduktif yang mengalami asam urat, terdapat sebanyak 42 yang mengalami peningkatan asam urat melebihi nilai normal yang terdiri dari 14 laki- laki dan 8 perempuan, 25 usia produktif sisanya mengeluh nyeri, dari 25 yang mengalami nyeri 10 orang mengatakan berobat ke dokter, 10 mengatakan memijat pada bagian yang sakit, 5 orang tetap melakukan aktivitas seperti biasa walaupun merasa nyeri. Program penyakit tidak menular pada masyarakat dengan usia produktif yang ada di puskesmas yang memberikan pelayanan khusus untuk masyrakat usia produktif serta di banjar ini belum pernah dilakukan penelitian tentang faktor yang mempengaruhi asam urat pada usia produktif.

Berdasarkan latar belakang diatas, peneliti tertarik untuk meneliti Faktor - 
Faktor yang Mempengaruhi Kadar Asam Urat Darah pada Usia Produktif di Desa Bukian, Kabupaten Karangasem.

\section{BAHAN DAN METODE}

Penelitian ini merupakan jenis penelitian korelasional yang bertujuan untuk menggungkapkan hubungan korelatif antara faktor makanan, faktor jenis kelamin, faktor tingkat pengetahuan, faktor aktifitas fisik. Pendekatan yang digunakan adalah cross-sectional yang menekankan waktu pengukuran atau observasi data hanya satu kali pada satu saat (Nursalam,2011)

Populasi pada penelitian ini adalah 67 usia produktif di Desa Nongan Kabupaten Karangasem. Sampel adalah bagian dari jumlah dan karakteristik yang dimiliki oleh populasi tersebut (Sugiyono, 2014). Sampel merupakan bagian atau wakil populasi yang diteliti.

Adapun kriteria inklusi dan eksklusi penelitian ini adalah kriteria inklusi : responden usia produktif yang berumur 18-45 tahun, masyarakat usia produktif yang bersedia menjadi responden, responden yang memiliki riwayat asam urat dan kriteria eksklusi adalah responden yang tidak bisa membaca dan menulis, responden yang tidak memiliki berat badan berlebih, responden yang tidak memiliki riwayat asam urat, responden yang tidak mengkonsumsi obat-obatan, responden yang tidak mengkonsumsi alkohol berlebih.

Instrumen penelitian merupakan alat yang digunakan untuk mengumpulkan data (Notoatmodjo, 2010). Instrumen pengumpulan data dalam penelitian ini adalah dengan menggunakan lembar kuesioner yang terdiri atas 24 pertanyaan yang mencakup makanan, tingkat pengetahuan, aktivitas fisik. Jenis kuesioner yang digunakan adalah check list yaitu sebuah daftar dimana responden tinggal membubuhkan tanda check atau centang $(\sqrt{ })$ pada kolom yang sesuai.

Uji validitas dalam penelitian ini dilakukan dengan menggunakan teknik korelasi product moment dengan bantuan program Statistical Product and Service Solutions (SPSS). Kriteria keputusan valid tidaknya kuesioner dinyatakan apabila hasil pengujian validitas pertanyaan-pertanyaan pada kuesioner menunjukkan korelasi positif pada level dibawah 0,05 dan terpenuhi tentang pearson's correlation product moment dari nilai tabel. Hasil uji valid tentang aktifitas fisik 0,546- 0,959. Hasil uji valid tentang makanan 0,675-0,875. Hasil uji valid tingkat pengetahuan 0,489-0,869. Uji reliabilitas pada instrument ini dilakukan menggunakan metode Alpha Cronbach dengan analisis komputer. Menurut Riwidikdo (2007), angka atau kuesioner dikatakan reliabel jika memiliki nilai alpha minimal 0,7 .

\section{HASIL}

Hasil Analisis Data Hubungan Pola Konsumsi Makanan Dengan Kadar Asam Urat Pada Usia Produktif di Desa Nongan Kabupaten Karangasem (lihat tabel 1.) 
Tabel 1. Korelasi Faktor Konsumsi Makanan Dengan Kadar Asam Urat Pada Usia Produktif di Desa NonganKabupaten Karangasem Tahun 2018

\begin{tabular}{|c|c|c|c|c|c|c|c|}
\hline & & & adar & sam I & & & \\
\hline & K & Nor & & Tidak & ormal & & \\
\hline छี & & $f$ & $\%$ & $\mathrm{f}$ & $\%$ & $\mathrm{f}$ & $\%$ \\
\hline ]్త & 1 & 0 & 0 & 0 & 0 & 0 & 0 \\
\hline बै & 2 & 16 & 27,6 & 5 & 8,6 & 21 & 36,2 \\
\hline$\sum$ & 3 & 4 & 6,9 & 33 & 56,9 & 37 & 63,8 \\
\hline$\frac{O}{2}$ & 4 & 20 & 34,5 & 38 & 65,4 & 58 & 100 \\
\hline$[\stackrel{\pi}{5}$ & 5 & 0,661 & & & & & \\
\hline & 6 & 0,000 & & & & & \\
\hline
\end{tabular}

Keterangan :

$1:$ rendah

2 : sedang

3 : tinggi

$4:$ total

5 : nilai $\mathrm{r}$

$6:$ nilai $\mathrm{p}$ value

$\mathrm{K}$ : kategori

Berdasarkan tabel 1. Nilai signifikansi yang di peroleh 0.000 sehingga $\mathrm{p}$ value $<$ 0.05. Hal ini menyatakan ada hubungan yang sangat signifikan antara faktor konsumsi makanan dengan kadar asam urat pada usia produktif.

Hasil Analisis Data Hubungan Aktivitas Fisik Dengan Kadar Asam Urat Pada Usia Produktif di Desa Nongan Kabupaten Karangasem (lihat tabel 2.)

Tabel 2. Korelasi Faktor Aktivitas Fisik Dengan Kadar Asam Urat Pada Usia Produktif di Desa NonganKabupaten Karangasem Tahun 2018

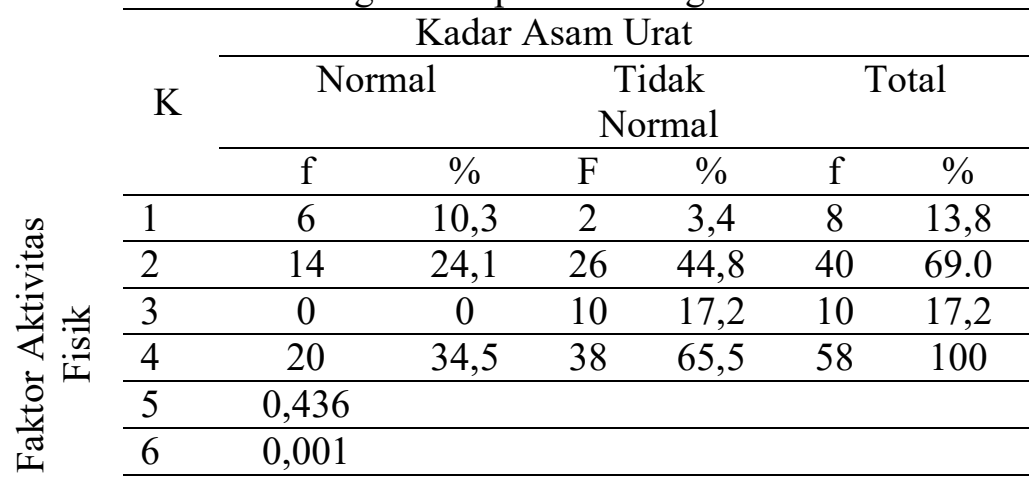

Keterangan :

$1:$ rendah

2 : sedang

3 : tinggi

$4:$ total 
5 : nilai $\mathrm{r}$

6 : nilai $\mathrm{p}$ value

$\mathrm{K}$ : kategori

Berdasarkan tabel 2. Nilai signifikansi yang di peroleh 0.001 sehingga $\mathrm{p}$ value $<0.05$. Hal ini menyatakan ada hubungan yang sangat signifikan antara aktivitas fisik dengan kadar asam urat pada usia produktif.

Hasil Analisis Data Hubungan Tingkat Pengetahuan Dengan Kadar Asam Urat Pada Usia Produktif di Desa Nongan Kabupaten Karangasem (lihat tabel 3.)

Tabel 3. Korelasi Faktor Tingkat Pengetahuan Dengan Kadar Asam Urat Pada Usia Produktif di Desa NonganKabupaten Karangasem Tahun 2018

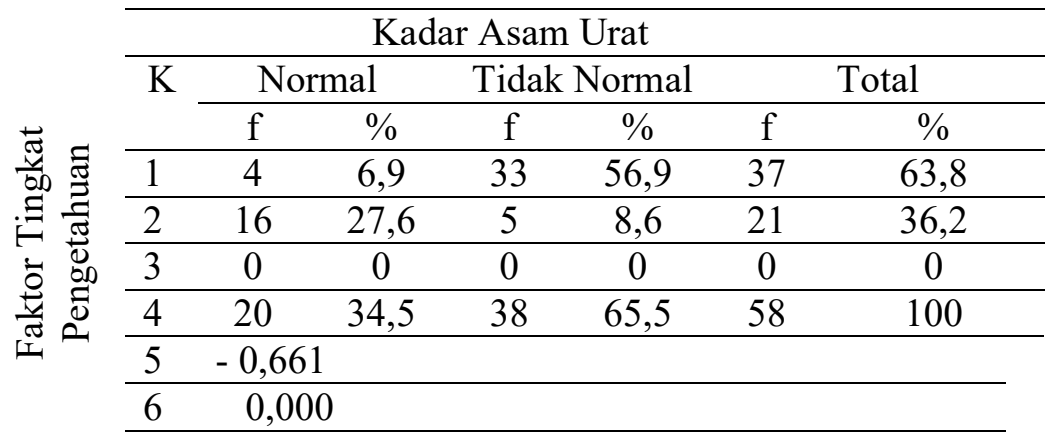

Keterangan :

$1:$ rendah

2 : sedang

3 : tinggi

$4:$ total

5 : nilai $\mathrm{r}$

6 : nilai $\mathrm{p}$ value

$\mathrm{K}$ : kategori

Berdasarkan hasil analisis pada tabel 3. Nilai signifikansi yang di peroleh 0.000 sehingga $\mathrm{p}$ value $<0.05$. Hal ini menyatakan ada hubungan yang sangat signifikan antara faktor tingkat pengetahuan dengan kadar asam urat pada usia produktif dengan arah korelasi negatif.

Hasil Analisis Data Hubungan Jenis Kelamin Dengan Kadar Asam Urat Pada Usia Produktif di Desa Nongan Kabupaten Karangasem (lihat tabel 4.)

Tabel 4. Korelasi Faktor Jenis Kelamin Dengan Kadar Asam Urat Pada Usia Produktif di Desa Nongan Kabupaten Karangasem Tahun 2018

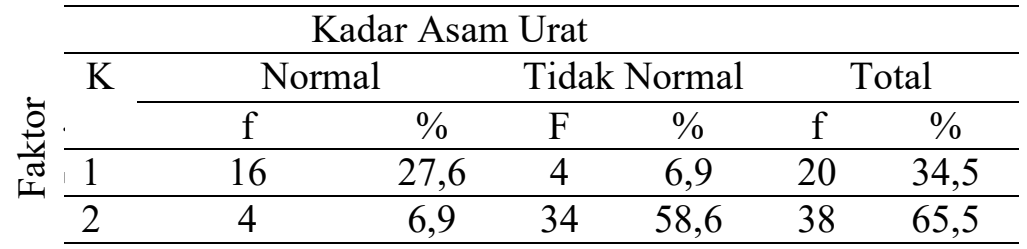




\begin{tabular}{ccccccc}
\hline 3 & 20 & 34,5 & 38 & 65,5 & 58 & 100 \\
\hline 4 & 0,695 & & & & & \\
\hline 5 & 0,000 & & & & & \\
\hline
\end{tabular}

Keterangan :

1 : perempuan

2 : laki-laki

3 : total

4 : nilai $\mathrm{r}$

5 : nilai $\mathrm{p}$ value

$\mathrm{K}$ : kategori

Berdasarkan hasil analisis pada table 4. Nilai signifikansi yang di peroleh 0.000 sehingga $p$ value $<0.05$. Hal ini menyatakan ada hubungan yang sangat signifikan antara Jenis Kelamin dengan kadar asam urat pada usia produktif.

\section{PEMBAHASAN}

Hasil uji hipotesis dengan sperman's rho diperoleh nilai korelasi 0,000 menunjukkan hubungan yang cukup signifikan maka dapat disimpulkan ada hubungan yang cukup signifikan antara konsumsi makanan dengan kadar asam urat pada usia produktif di Desa Nongan Kabupaten Karangasem. Hubungan positif bermakna semakin sering seseorang mengkonsumsi makanan yang mengandung tinggi purin semakin tinggi pula kadar asam urat dalam darah. Hasil Penelitian ini sejalan dengan penelitian yang dilakukan oleh Ren, et al (2016), pola makan dengan konsumsi makanan yang tinggi protein, dalam hal ini misalnya ikan laut merupakan pemicu kejadian penyakit gout di negara Jepang.

Berdasarkan analisa hubungan yang dilakukan antara aktivitas fisik dan kadar asam urat nilai koefisien kontingensi atau $p$ sebesar $0,001(\mathrm{p}<0,05)$. Maka dapat disimpulkan bahwa ada hubungan signfikan antara aktivitas fisik dan kadar asam urat. Hal ini sejalan dengan hasil penelitian eksperimental yang dilakukan oleh Beavers dkk, (2014) yang menyebutkan bahwa subjek dengan intervensi aktivitas fisik sedang selama 12 bulan memiliki risiko peningkatan asam urat 4,8\% $(0,24$ $\mathrm{mg} / \mathrm{dl}$ ) jika dibandingkan dengan subjek tanpa intervensi aktivitas fisik.

Hasil uji analisis sperman's rho diketahui bahwa ada hubungan antara tingkat pengetahuan dengan kadar asam urat pada usia produktif di Desa Nongan Kabupaten dengan nilai koefisien kontingensi atau p sebesar $0,000(p<0,05)$, maka dapat disimpulkan ada hubungan yang cukup signifikan antara tingkat pengetahuan dengan kadar asam urat pada usia produktif di Desa Nongan Kabupaten Karangasem. Dimana pengetahuan dengan arah negatif artinya ada hubungan negatif antara tingkat pengetahuan dengan kadar asam urat. Hasil ini didukung oleh penelitian yang dilakukan oleh Dharmayuda (2008), yang meneliti tentang hubungan pemberian diit rendah purin pada penderita artritis dengan penurunan kadar asam urat, dimana hasil diketahui bahwa pemberian diit rendah purin selama 7 hari pada 30 penderita artritis dapat menurunkan kadar asam urat dari 10,41 \pm $2,43 \mathrm{mg} / \mathrm{dl}$ menjadi $10,32 \pm 2,35 \mathrm{mg}$ yang secara statistik bermakna dengan $p<$ 0,001 .

Berdasarkan analisa hubungan yang dilakukan dengan uji analisis sperman's 
rho diketahui bahwa ada hubungan antara jenis kelamin dengan kadar asam urat pada usia produktif di Desa NonganKabupaten Karangasem dengan nilai korelasi 0,000 menunjukkan hubungan yang cukup signifikan maka dapat disimpulkan ada hubungan yang cukup signifikan antara jenis kelamin dengan kadar asam urat pada usia produktif di Desa Nongan Kabupaten Karangasem. Hal ini sejalan dengan apa yang diungkapkan oleh Saito et.all.( 2010) yang menyatakan bahwa Kadar asam urat pada pria lebih tinggi dibanding perempuan, karena pria mempunyai hormon androgen yang dapat memicu reabsorpsi asam urat pada sistem transpor ginjal. Hal tersebut berhubungan dengan testosteron yang berkontribusi meningkatkan masa otot pria, dengan menjadikan hiperurisemia sebagai sumber purin yang besar sehingga mempengaruhi reabsorpsi ginjal pada pria. (Mahmood et.al., 2013).

\section{SIMPULAN DAN SARAN}

\section{Simpulan}

Berdasarkan hasil penelitian tentang faktor -faktor yang mempengaruhi kadar asam urat darah pada usia produktif di desa bukian, kabupaten Karangasem dapat disimpulkan sebagai berikut :

Hasil analisis hubungan antara konsumsi makanan dengan kadar asam urat pada usia produktif di Desa Nongan, Kabupaten Karangasem diketahui koefisien korelasi (r) variabel Makanan sebesar 0,661. Nilai signifikansi yang di peroleh 0.000 sehingga $\mathrm{p}$ value $<0.05$. Hal ini menyatakan ada hubungan yang sangat signifikan antara faktor konsumsi makanan dengan kadar asam urat pada usia produktif.

Hasil analisis hubungan antara aktivitas fisik dengan kadar asam urat pada usia produktif di Desa Nongan, Kabupaten Karangasem diketahui koefisien korelasi (r) variabel aktivitas fisik sebesar 0,436. Nilai signifikansi yang di peroleh 0.000 sehingga $p$ value $<0.05$. Hal ini menyatakan ada hubungan yang sangat signifikan antara aktivitas fisik dengan kadar asam urat pada usia produktif.

Hasil analisis hubungan antara tingkat pengetahuan dengan kadar asam urat pada usia produktif di Desa Nongan, Kabupaten Karangasem diketahui koefisien korelasi (r) variabel tingkat pengetahuan -0,661. Nilai signifikansi yang di peroleh 0.000 sehingga $\mathrm{p}$ value $<0.05$. Hal ini menyatakan ada hubungan yang sangat signifikan antara faktor tingkat pengetahuan dengan kadar asam urat pada usia produktif dengan arah korelasi negatif.

Hasil analisis hubungan antara jenis kelamin dengan kadar asam urat pada usia produktif di Desa Nongan, Kabupaten Karangasem diketahui koefisien korelasi (r) variabel jenis kelamin sebesar 0,695. Nilai signifikansi yang di peroleh 0.000 sehingga $p$ value $<0.05$. Hal ini menyatakan ada hubungan yang sangat signifikan antara Jenis Kelamin dengan kadar asam urat pada usia produktif.

\section{Saran}

Kepada Puskesmas:Bagi perawat khususnya pada bagian promosi kesehatan agar lebih sering memberikan pendidikan tentang asam urat. Bagi peneliti selanjutnya agar dapat melakukan penelitian lebih lanjut dengan mempertimbangkan berbagai faktor lain yang berkaitan dengan asam urat, serta dapat memberikan makna faktor apa kira-kira yg paling berpengaruh untuk 
munculnya asam urat dengan melakukan uji multivariate untuk memaknai hasil penelitian selanjutnya. Bagi usia produktif diharapkan dapat lebih menjaga kesehatannya dengan mengatur pola makan, dengan mengurangi mengkonsumsi makanan yang tinggi purin yang menjadi faktor resikoterjadinya asam urat seperti jeroan, daging, bayam, ikan sarden dan kacang-kacangan (kacang merah dan kacang meninjo).

\section{DAFTAR PUSTAKA}

Depkes RI, 2009. Sistem Kesehatan Nasional. (online) (www.depkes.go.id.diakses Pada Tanggal 1 April 2018.)

Fatmah, 2010. Gizi Usia Lanjut . Jakarta : Erlangga

Hidayat, 2006. Pengantar Kebutuhan Dasar Manusia : Aplikasi Konsep dan Proses Keperawatan. Jakarta : Selemba Medika.

Hidayat A. 2007. Metode Penelitian Keperawatan dan Teknik Analisa Data. Penerbit Salemba Medika : Jakarta

Junaidi, I. 2012. Rematik Asam Urat-Hiperusimia Arthritis Gout. Jakrata : PT Bhuana Ilmu Populer.

Krisnatuti, 2006. Perencanaan Menu untuk Penderita Gangguan Asam Urat. Jakarta: Penbar swadaya

Laode, 2012. Asuhan Keperawatan Gerontik Berdasarkan Nanda Nic dan Noc. Yogyakarta : Nuha Medika.

Notoatmodjo, Soekidjo. 2010. Promisi Kesehatan dan Perilaku Kesehatan. Jakarta: Rineka Cipta.

Nursalam, 2011. Konsep dan Penerapan Metodelogi Ilmu Keperawatan. Jakarta : Salemba Medika

Nursalam. 2017. Metodologi Penelitian Ilmu Keperawatan : Pendekatan Praktis Edisi 4, Jakarta : Salemba Medika.

Riset Kesehatan Dasar (Riskesdas).2013. Badan penelitian kesehatan kementerian RI tahun 2013.

Riwidikdo. 2007. Metodelogi Penelitian Kesehatan. Jakarta. Bina Pustaka.

Sarwono, S.W. Psikologi Remaja Edisi Revisi. Jakarta : PT Raja Grafindo Persada. 2012 .

Sugiono, 2014. Metode Penelitian Kuantitatif, Kualitatif dan $R \& D$, Bandung : Alfabeta. 